\title{
TRANSITIONAL JUSTICE, VICTIMS AND HUMAN RIGHTS \\ IN THE LIGHT OF INTERNATIONAL LAW \\ AND THE INTER-AMERICAN SYSTEM OF HUMAN RIGHTS
}

\author{
FLORABEL QUISPE REMÓN ${ }^{1}$
}

\begin{abstract}
The article begins by analyzing the origin and evolution of the concept "transitional justice", determining its characteristics, the context in which it was born and developed, as well as the role of the State in this process. Then it focuses attention on analyzing the development of this figure in the jurisprudence of the Inter-American Human Rights System, through the work that the Inter-American Court has been carrying out since its operation, interpreting in a broad way and always pro homini, the American Convention of Human Rights. Throughout its years of operation, it has ruled on the State's obligation to protect and guarantee human rights and to carry out the pertinent investigations in the event of their violation; as well as the recognition of the status of victims to the victims' families and their pronouncement of the right to the truth, not as an autonomous human right, but rather as a right of the victims and their next of kin. Undoubtedly, these are aspects that have gone beyond the American Convention.
\end{abstract}

Keywords: Transitional justice, human rights, inter-American court, truth, victim.

Summary: 1. Introduction. 2. Origin and Evolution of Transitional Justice in International LAW. 2.1. Background and development of Transitional Justice. 2.2. Concept of transitional Justice and its relationship with International Human Rights Law. 2.3. Characteristics of transitional justice. 2.3.1. Determination of victims and investigations after a dictatorship or armed conflict. 2.3.2. Establishment of mechanisms to alleviate the consequences of serious and systematic violations of human rights seen from practice. 2.4. Recognition of Transitional Justice at the United Nations. 2.5. The Chicago Principles on Transitional Justice. 3. Transitional Justice in the Inter-American Human Rights System. 3.1. Brief reference to the creation of transitional Justice in Latin America and the Inter-American human rights system. 3.2. The Inter-American Court and its development of transitional justice elements. 3.2.1. The next of kin of victims and their consideration as victims by the Inter-American Court. 3.2.2. The right of victims to the right to the truth according to the Inter-American Court. 4. Final Reflections. 5. Bibliography.

\section{INTRODUCTION}

The great internal and/or international conflicts, armed or not, and the dictatorships in various parts of the world have as a consequence led to, on the one hand, great suffering for human beings, and on the other hand, the adoption in many cases of amnesty laws, synonymous with forgetting and abandoning people who have experienced such suffering brought about by the State and, why not say it, also by society. That is what impunity means. There are many States, among others, Chile, Paraguay, Uruguay, that did not

\footnotetext{
1. Professor of Public International Law. Universidad Carlos III de Madrid, Spain (fquispe@der-pu.uc3m.es). This article has been written within the framework of the Research Project ODS, Derechos Humanos $y$ Derecho Internacional (PGC 2018-095805-B-100).
} 
carry out relevant investigations and pursue consequences, unlike Argentina, which has singled out and prosecuted the military for their role in repression (PION-BERLIN, 1995, p. 82) In a democratic State, the State is in charge of protecting human rights (Human Rights) of all people who are under its jurisdiction regardless of their nationality. After all, human rights are the limit to the absolute will of the States. The State has the obligation to guarantee the effective enjoyment of human rights, and for this, it must have adequate and honest mechanisms, which, if applicable, carry out pertinent investigations to find those responsible for the violations, prosecute them, with the necessary corresponding guarantees and condemn them. This contributes to the fight against impunity and makes the victims trust their protection system and feel the State is on their side. However, in practice, we note that one of the characteristics of dictatorships or conflicts is the absence of respect for human rights. In this context, taking into account the progress and increasing commitment by the international community to the establishment and consolidation of democratic societies, and due to the recognition and respect of human rights, the figure known as "transitional justice" (TJ) of the State arises in the protection of their rights, that is, for the victims. For this reason, certain authors have defined it "as the conception associated with periods of political change", a justice that arises and is applied between one political regime and another (O'DONNELLL \& SCHEMITTER, 2003, p. 69). A justice that seeks to recognize the victims, investigate the facts and redress them, if it is the case, in some way all the suffering experienced. However, there is no single recipe for the measures to be adopted, nor a specific omnipotent authority to decide which measures to adopt after the "storm", which leads to the discussion of what measures should be applied and who is authorized to know what is really needed or to meet the needs of the victims and the population in general. MÉNDEZ, taking into account what has been experienced in Latin America (LA) and in other parts of the world in the attempt to restore truth and justice, includes certain principles that are generally applied, and disagrees with the affirmation that democratic leaders are the ones who best know the needs of their society at a given moment, and thus, not suitable to impose rules about what to do with the recent past (MÉNDEZ, 1997, p. 255). He argues that democratic leaders should only fight to restore the truth of the recent past and, "in general, avoid any attempt to restore justice, at least through criminal proceedings. As mentioned before, from the point of view of International Human Rights Law, States have the obligation to protect the rights of all persons who are under their jurisdiction from the moment of ratification of international instruments. However, we must bear in mind that these international instruments do not refer to "transitional justice", although both are aimed at human being; and in this context, it is of interest to know the position or interpretation of the human rights protection bodies of the human rights treaties with reference to transitional justice.

Therefore, given the importance of the subject for demanding rights and / or obtaining justice, the present work aims, first of all, to briefly analyze, given the limitations of the scope of the work, the figure of JT, examining its origins, its evolution, its characteristics, its scope and its relationship with victims and human rights; and secondly, once the issue has been contextualized, analyze its treatment in international law, specifically in the jurisprudence of the Inter-American Court of Human Rights (Inter-American Court of Human Rights) to see how this judicial body of the inter-American Human Rights system (IHRS) has interpreted / developed the JT, with special emphasis on the justice 
element. The analysis of the jurisprudence of the Inter-American Court is important, first, because a large part of the States that are now part of the IASR, and have assumed the contentious jurisdiction of the Court, have suffered dictatorships or armed conflicts, where application of a JT was necessary; and second, because in the Latin American regions the jurisprudence of the Inter-American Court, due to the development of conventionality control by the Inter-American Court, acquires special relevance because the States that assumed the jurisdiction of the Court would be obliged to incorporate their jurisprudence into their domestic law.

For this, it is necessary to resort to the authorized doctrine, to some resolutions of International Organizations such as the United Nations, and especially to the jurisprudence of the Inter-American Court, the main objective of our study. This is done through legal dogmatic methodology, first addressing the general framework of transitional justice, and then addressing its development in International Law, especially in the interpretation that the Inter-American Court has developed of this figure, under the American Convention of Human Rights. The analysis goes from the general to the specific, to finalize with some conclusions.

\section{Origin and Evolution of Transitional Justice in International LaW}

\subsection{Background and development of Transitional Justice}

This is an expression coined in the 1990s by US academics, "To refer to the different ways that countries had to solve the problems that arose when a government came to power after its predecessors committed massive rights violations" ${ }^{\text {"2 }}$. This ended up having repercussions especially in the US "due to the great interest that there was in knowing how the former countries of the Soviet bloc would deal with the legacy of totalitarianism"3. Thus, in the words of Roht-Arriaza, "the study of how societies emerging from periods of civil war or dictatorships deal with the legacies of the past became a full-fledged subject of academic inquiry and human rights activism during the 1990s" (ROHT-ARRIAZA, 2006, p. 1).

Some authors have referred to three phases in the evolution of TJ. TEITEL locates its origin in the First World War, but the three phases they mention are located in contemporary international law. These are summarized in the following figure (Fig. 1):

In these phases, the mention of what happened in LA is missing. For the International Center for Transitional Justice (ICTJ), the approach that we have today came about in the late 1980s and early 1990s, in response to political changes and demands for justice in this region and in Eastern Europe to face the great and serious systematic violations of human rights of the previous regimes, but without jeopardizing the political

\footnotetext{
2. A broad development on the origin and evolution can be found in: The International Center for Transitional Justice. Available at: https://www.ictj.org/es/que-es-la-justicia-transicional (Accessed: 22 March 2021). See also (TEITEL, 2000).

3. Idem
} 


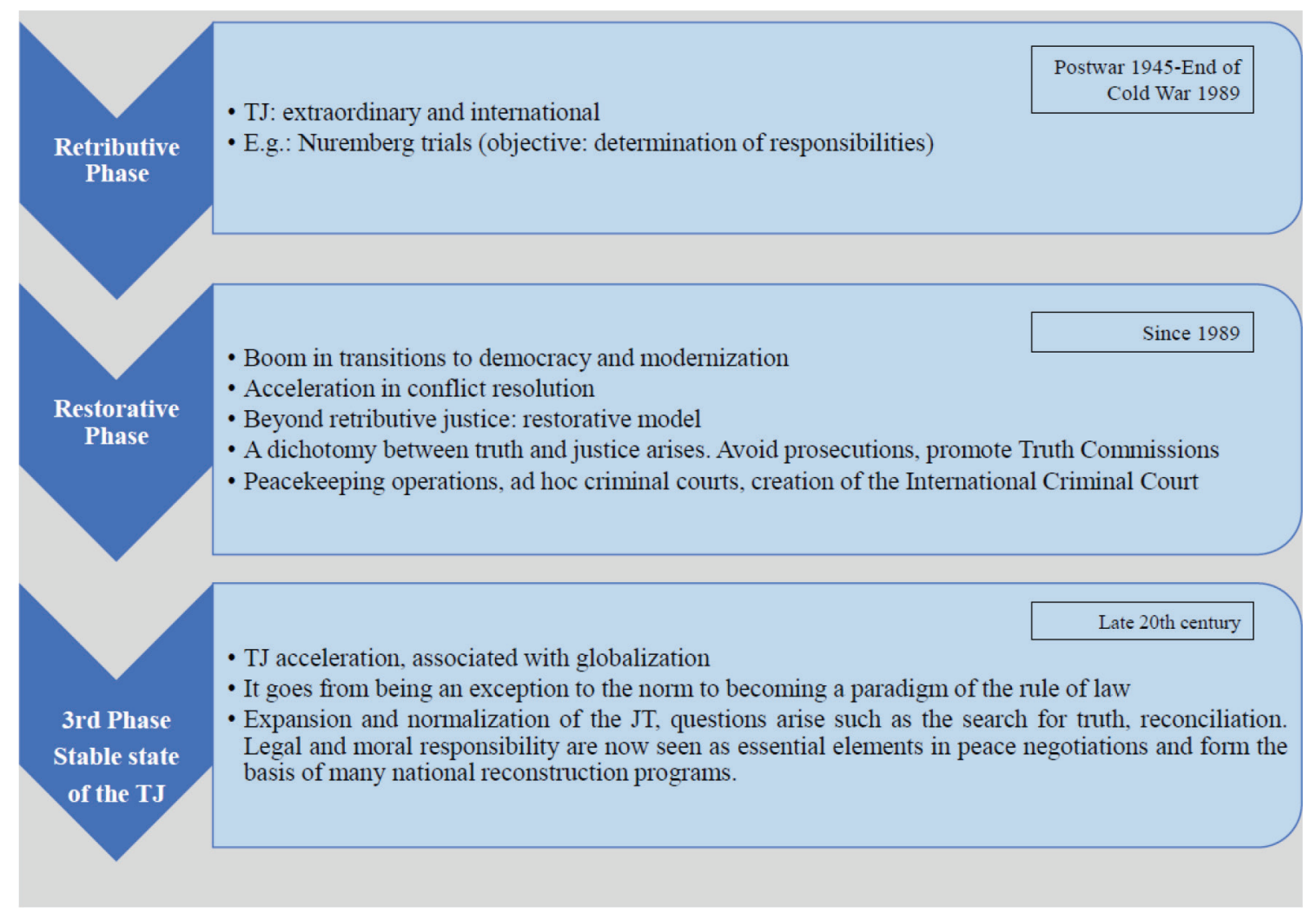

Figure 1

Source: Own elaboration based on (SERSALE DI CERISANO, 2013) and (TEITEL, 2003).

transformations put in place. "Given that these changes were popularly known as transitions to democracy," this new multidisciplinary field began to be called "transitional justice." 4 Aspects established by governments at that time have become basic approaches to TJ, such as criminal prosecutions, truth commissions, reparation programs, a gender approach to justice, legal and institutional reforms, and commemoration initiatives. ${ }^{5}$ Thus, many agree that since the mid-1980s there has been an interest in transitional justice linked to a series of political transitions from authoritarian to democratic regimes. As of that year, a wave of democratization spread throughout Latin America marked by shouts of "never again", demanding accountability for human rights abuses under authoritarian regimes in Argentina, Chile and elsewhere. The lesson of the Latin American experience extended to democratic transitions in other parts of the world (WILLIAMS, et al., 2012, p. 3). "Accountability for past abuses among human rights activists was taken up at the international level, where the focus on political change as "transition to democracy" helped to legitimate those claims to justice that prioritized legality. Institutional reforms and responses - such as punishing leaders, vetting abusive security forces, and replacing state secrecy with truth and transparency - on other claims to justice that we oriented toward social justice and redistribution" (PAIGE, 2009, pp. 321-322). So much so that "In

\footnotetext{
4. Available at: https://www.ictj.org/sites/default/files/ICTJ-Global-Transitional-Justice-2009-Spanish.pdf, p.1 (Accessed 17 March 2020). Along these lines, see (PAIGE, 2009). 5. Idem
} 
Central and South America, many countries began processes of change from systematic repression to greater openness and democratic participation." 6 This contributed, what is more, to creating criminal proceedings, truth commissions, reparation policies and commemoration mechanisms, civil society and local human rights groups, exerting social pressure. On the other side of the Atlantic, in Eastern and Central Europe, governments developed initiatives linked to greater breadth of public debate, commemoration, opening of security files and the implementation of administrative notes known as "purging" or "disabling". These TJ strategies emerged from the bottom up as a derivation of popular movements and in response to local experiences or demands. ${ }^{7}$

The truth is that the phases and what happened in AL have been oriented to the protection of human beings, recognizing their status as victims and their dignity, redressing the consequences of the violations and punishing, where appropriate, those responsible for said violations. It was about rendering accounts of the past, an essential aspect for a peaceful coexistence, trying to overcome grudges and resentments, and for strengthening of the rule of law. In this process, it contributes to the development of human rights protection systems, which creates obligations for the States to recognize and guarantee human rights.

The context in which the TJ "paradigm" arises, according to DE GREIFF, former Truth and Justice rapporteur, has two characteristics; first, the measures were applied in countries with relatively high degrees of both horizontal and vertical institutionalization, although this was not enough to prevent abuses. It was a breakdown of the institutionality and therefore part of the objective of the transition could be understood as the recovery of interrupted traditions and institutions; second, the measures were adopted in response to a certain type of violation, that is, those associated with the abusive exercise of power. This shows the deep connections between these two factors; only relatively institutionalized and efficient states can commit violations of a certain degree of magnitude, but above all, of systematicity" (DE GRIEFF, 2011, p. 17).

Likewise, this author characterizes the context in which the JT measures operate and points out that the term JT finds its natural place in "a very imperfect world", understood as one in which there is no spontaneous generalized compliance with even a basic norm. Furthermore, he states, "It is characterized not just by the massive and systematic violations of norms but also by the fact that there are huge and predictable costs associated with the very effort to enforce compliance. At the limit, in such a world, that effort puts at risk the very existence of the system that is trying to enforce its own norms". This, according to what DE GRIEFF believes, is the main domain for application of the term transitional justice (DE GRIEFF, 2012, p. 35).

\footnotetext{
${ }^{6 .}$ Cfr. The Chicago Principles on Transitional Justice, a joint project of the "“'International Human Rights Law Institute", "Chicago Council on Global Affaire", Instituto Superiore Internazionale di Scienze Criminali” y la "Association Internationale de Droit Pénal", dirigido por M. Cheriff Bassiouni, p. 8-9. Available at: .https:// biblioteca.iidh-jurisprudencia.ac.cr/index.php/documentos-en-espanol/verdad-justicia-y-reparacion/1312los-principios-de-chicago-sobre-justicia-transicional/file (Accessed 2 April 2021). 7. Idem.
} 


\subsection{Concept of transitional Justice and its relationship with International Human Rights Law}

However, pointing out that the term JT is itself a bit slippery, Roht-Arriaza defines it as the "conception of justice associated with periods of political change, Characterized by legal responses to confront the wrongdoings of repressive predecessor regimes" (ROHTARRIAZA, 2006, p. 1). Jeremy Weber observes that transitional justice deals with situations in which a society goes from a state of injustice to justice, from an oppressive government to a government that respects the rule of law, from authoritarianism to democracy. It deals with the administration of justice through such a regime change. Hence, its central questions: to what extent and according to what standards is it appropriate to judge the events that occurred during the previous regime? What kind of process, what forms of recovery from punishment, are appropriate in such circumstances (WEBER, 2012, p. 98)? The truth is that the JT seeks recognition of the dignity of people, the recognition of rights violations, justice, truth, reparation, and non-repetition.

The TJ and International Law of Human Rights were both created almost in parallel, but the development of the international protection systems for human rights has been much faster. Both human rights and International Criminal Law (ICL) contribute to its consolidation. The application of the TJ occurs after a dictatorship or armed conflict (Colombian case) $)^{8}$, generally by the new authority or the transitional government through the adoption of new mechanisms or reactivating existing ones that were not applied during the dictatorship and / or conflict. However, as ZALAQUETT pointed out, at the beginning, dealing with transitional political situations was a new part of human rights practice that raised some complex ethical, legal and practical questions. For the most part, Zalaquett states, human rights organizations have entered this new area by applying, by extension, the normative standards and techniques they used when fighting current abuses by governments. This author wonders, among others questions, if a set of standards can be inferred from international norms and general legal principles, to be applicable to the problem of addressing past human rights abuses. Under what circumstances, if there are any, can a government excuse itself from complying with such obligations on the grounds that it is not in its power to do so? And based on a generalized opinion of academics and professionals, it indicates that it must maximize the responsibilities of the new government. Therefore, he says, the trend is: to emphasize the responsibility of governments, regardless of whether they actually have real power or are simply the holders of power; insist on the continuity of the State's obligations despite changes in government, especially with regard to the promotion and respect of human rights; argue that governments also have indirect responsibility when non-governmental groups commit abuses, to the extent that it is their duty to maintain order and enforce the law. This approach is, in principle, the correct one, insofar as it is based on the bias that any attempt to dilute the responsibility of the government could weaken the protection of human rights and the rule of international law (ZALAQUETT, 1995, p. 3).

\footnotetext{
8. On JT in Colombia see among others (GUEMBE \& OLEA, 2006).
} 
Progress in this regard in recent decades has been enormous. It is understood that it is the responsibility of government to assume past human rights violations by adopting the necessary mechanisms to clarify the facts.

The mechanisms can be judicial, such as the creation of ad hoc tribunals to investigate and convict those responsible, or non-judicial ones, such as truth commissions, to investigate the facts, thus recognizing the rights of the forgotten victims during the period of the violations. It is the stage in which the State assumes the commitment to "heal the wounds" and seek reconciliation in society between "those who have injured and the injured", it is to seek peace. It is about doing justice, seeking the truth, investigating the facts, and making amends to the victims.

It is "a response to systematic or generalized human rights violations. Its objective is to recognize the victims and promote initiatives for peace, reconciliation and democracy. It is not a special form of justice, but rather justice adapted to societies that transform themselves after a period of generalized violation of human rights. In some cases, these transformations happen from one moment to the next; in others, they can take place after many decades". DE GRIEFF points out that it is a set of measures that can be implemented to address the legacy of massive human rights abuses, where "addressing the legacy" means demonstrating the validity of human rights regulations that were systematically violated through criminal prosecution, the search for the truth, reparations and institutional reform (DE GRIEFF, 2011, p. 28). For this author, the TJ that was created in practice and crystallized in the Southern Cone, in order to solve specific problems, has become a "universal tool" that apparently solves diverse problems, regardless of the context. ${ }^{10}$ In the words of DORADO, it is a movement that in its beginnings was fed by the experiences of Latin America and Eastern Europe and "that has been learning about new developments and incorporating the consideration and treatment of deeper and more complete conflicts such as those in Rwanda, the former Yugoslavia, East Timor, Sierra Leone, Democratic Republic of the Congo, Colombia, etc. ". The reality and challenges that TJ processes must face have been changing, "introducing more complex situations that directly relate transitional justice mechanisms to peace and conflict resolution practices and the need to promote social and economic development, good governance or ways to include affected groups in the reconstruction process" (DORADO, 2015, p. 193). Along the same line as (SCHABAS, 2006).

The truth is that the ultimate goal of the TJ is to promote justice, although it will depend, as DE GRIEF says, on the concept that justice is given. In sum, its three purposes are the recognition of victims, promoting civic trust and strengthening the norm of democratic law (DE GRIEFF, 2011, p. 28).

\footnotetext{
9. Available at: https://www.ictj.org/sites/default/files/ICTJ-Global-Transitional-Justice-2009-Spanish.pdf, p.1 (Accessed 17 March 2020)

${ }^{10 .}$ Idem, p.17.
} 


\subsection{Characteristics of transitional justice}

\subsubsection{Determination of victims and investigations after a dictatorship or armed conflict}

The end of dictatorships or conflicts or the transition to democracy do not automatically imply the beginning of the TJ, nor is it immediate; it takes time and can take many years or even never happen. As Roht-Arriaza points out, in practice the "transition" may span many decades and may last longer for some issues than others (ROHTARRIAZA, 2006, p. 1). For this reason, TJ should not be limited to a formal approach since they are not sufficient to meet the needs of the victims and of society in general, "it should be thought of as a multifaceted and interdisciplinary whole, and the design should be carried out with social, cultural, historical and political sensitivity". The measures must include judicial proceedings, truth commissions, reparations, investigation, sanctions and administrative measures, commemoration, education and archives and institutional reform (SERSALE DI CERISANO, 2013, p. 117). The reality and the particularities of the population in which it is applied must always be taken into account. The study of the context is essential, "the political, social and legal conditions of the country will determine what can be done and when", as well as cultural aspects and religious beliefs (KASAPAS, 2008, p. 59). Creativity and innovation are not enough, but other important aspects, which increase the chances of success of the TJ. Rigid approaches and the to-do lists should be avoided ${ }^{11}$. A body should be created to carry out the pertinent investigations to find out the truth and identify the victims, and another to help and facilitate the lives of victims and those who live in difficult contexts. These bodies must meet the basic requirements such as knowing the context, reality, language, and empathizing with the population's problems. They must inspire confidence and independence in the population. It could be a truth commission or any other body whose purpose is to search for the truth and have a list of victims. Mechanisms should be established to carry out the pertinent police and judicial investigations, with the corresponding guarantees, in order to avoid impunity. In addition, resources should be allocated to provide adequate health, social and economic care to the victims and / or their families. Recognition by the State of what happened is relevant, as is recording for history what happened through collection of information from the past together with the necessary measures to vindicate the dignity of the victims, since it is in charge of assuming the events of the past and facing them in a way that guarantees reparation to the victims, focusing attention on the eradication of human suffering regardless of the reasons (wars or dictatorships) that have created the violation.

Nevertheless, there is no formula applicable to all cases, each case is unique, although taking into account its development, a common denominator can be established. The aspects that characterize the TJ, among others, are the investigations to determine identification of the victims, and determination of responsibilities and reparations.

Always assuming there is no perfect solution, the limited scope of each of the measures that are part of a JT policy must be recognized, as DE GRIEF affirms, from the outset. "In fact, there is no transitional country that can legitimately claim great

\footnotetext{
${ }^{11 .}$ https://www.ictj.org/es/que-es-la-justicia-transicional (Accessed 17 March 2020)
} 
successes in this area. That is, there is no country that has undergone a transition that has prosecuted each and every perpetrator of human rights violations (let alone punished them in proportion to the gravity of the harm they caused); that has implemented a truthseeking strategy that disclosed the fate of each and every victim or thoroughly identified the structures that made the violations possible; that has established a reparations program providing each and every victim with benefits proportional to the harm he or she suffered; or that, particulary in the short run, has reformed each and every institutions that was implicated in the violations in question" (DE GRIEFF, 2012, p. 35).

\subsubsection{Establishment of mechanisms to alleviate the consequences of serious and systematic violations of human rights seen from practice}

The measures following the major human rights violations by the authority in power, to "heal the wounds of the past" and close the cycle, can be "oblivion" or measures to avoid impunity and recognizing the dignity of the victims.

\subsubsection{Mechanisms oriented to forgetting}

Its objective is to close one stage and start another, under the slogan "blot and clean slate" and protected by impunity. These are the amnesty laws and prescriptions for those responsible for systematic violations, which have caused harm to direct and indirect victims of violations, preventing investigations of large and serious human rights violations in the world. Today, fortunately, they do not fit in a democratic society because they are incompatible with the International Law of Human Rights ${ }^{12}$. The consolidation of all the democracies in the world and the development of human rights allow the cases to be reactivated and removed from oblivion, to initiate an investigation (HUNTINGTON, 1994, p. 263) $)^{13}$. According to the CIJT, the TJ describes different approaches in different places, not a coherent concept or practice", then in the 1990s and 2000s new approaches and practices were born, based on the recognition of principles related to human rights where it was unthinkable to ignore their violation. Mechanisms such as judicial processes, investigations (or "truth-clarification" initiatives), reparation programs and reform proposals were linked to this, which were considered the most effective in materializing that respect for human rights"14. Today, in the midst of 2021, it is difficult to apply the mechanism of forgetting, a "blot and clean slate"- Here, international human right treaties and their development play an important role through the interpretation made by them, their bodies, judicial or not, as well as international actors, making the problem visible and pressing for the adoption of measures to repair the events of the past and avoid impunity by the State of transition.

\footnotetext{
12. Fortunately, international human rights bodies have had the opportunity to pronounce that amnesties and human rights requirements are incompatible with the obligations of States to investigate human rights violations. (I/A Court HR, 2011b), (UN, Human Rights Committee, 1992) Cf. I/A Court HR of Human Rights, among others, Gelman v. Uruguay, February 24, 2011, Human Rights Committee, General Comment No. 20, 44 period of sessions, 1992.

13. Although "in 1990, approximately two-thirds of the countries of the world did not have democratic regimes."

14. https://www.ictj.org/es/que-es-la-justicia-transicional (Accessed 17 March 2020)
} 


\subsubsection{Mechanisms aimed at remembering and claiming rights}

These may or may not be judicial, as we mentioned above, with a single purpose, to achieve justice, which involves recognizing the dignity of the victims and the fight against impunity. Today, a large part of the world states have assumed the obligation to recognize, protect and guarantee human rights through the ratification of international rights, and in this context they are obliged to carry out the pertinent investigations to avoid impunity. According to MENDEZ, in a few years there has been great progress regarding the recognition that serious and systematic violations generate obligations of the State towards the victims and society. However, considerable disagreements remain about the content of these obligations and how they should be fulfilled. For this author, the obligations are multifaceted and can be fulfilled separately, but in no case should they be seen as alternatives to one another. "The different obligations are not a menu from which the Government can choose a solution; they are in fact different obligations, each of which must be fulfilled in accordance with the best possibilities available to the Government. It considers judicial processes with all the guarantees essential in any serious effort to accountability" (MÉNDEZ, 1997, pp. 255-256). Faced with crimes against humanity, States must: "investigate, prosecute and punish the perpetrators; reveal to the victims, their families and the whole of society everything that can be reliably clarified about these events; offer the victims the reparations due; and separate the fully identified executioners from the security forces and other positions of authority". Their obligation to those who have acquired a specific right consisting of: The right of victims to receive justice, know the truth, receive compensation and other forms of non-monetary restitution, and the right to new, reorganized and responsible institutions. These are rights that not only benefit the victim, but also society as a whole (MÉNDEZ, 1997, pp. 261-262)

\subsection{Recognition of Transitional Justice at the United Nations}

The TJ was incorporated into the United Nations by the Secretary General in 2004 through the report entitled "The rule of law and transitional justice in societies that suffer or have suffered conflicts" (United Nations, General Secretariat, 2004). It shows the interest of the UN in addressing the issue and in the actions to be taken, highlighting the need to reach a common foundation for international norms and standards. It highlights the importance of commitment to and investing in justice, not resorting to mere formulas, which are the same for all, nor importing foreign models, but taking into account each reality, needs, aspirations and the participation of the countries themselves. In this process, the States play a fundamental role and, in this context, it is committed to promoting the technical capacity for reform, as well as the political will to implement it.

It makes it clear that justice, peace and democracy are not mutually exclusive but rather imperatives that reinforce one another. For this reason, it considers it essential for achievement of these three objectives "a strategic planning, a careful integration and a sensible sequence of activities. It would be useless to focus exclusively on a certain institution or to dismiss civil society or victims. In the justice sector, we must pay full attention to all its interdependent institutions, take into account the needs of key groups 
and not forget the need for transitional justice mechanisms to be complementary. Our main role is not to create international mechanisms to replace national structures, but to help build national capacity in the field of justice" 15 .

Along the same lines, the Security Council in 2010 showed its position against impunity for the commission of serious violations of IHL and human rights standards, and advocated for the defense of accountability through the use of means, such as national, international and mixed criminal courts and tribunals, truth and reconciliation commissions, national reparation programs for victims, institutional reforms and traditional dispute resolution mechanisms. This affects the responsibility of the State to put an end to impunity and its obligation to "seek sustainable peace, justice, truth and reconciliation"16, as well as their willingness "to ensure that all UN activities aimed at restoring peace and security respect and promote the rule of law".

In 2005, the UN General Assembly approved the Basic Principles and Guidelines on the right of victims of gross violations of international human rights standards and serious violations of IHL to file remedies and obtain reparations ${ }^{17}$. An instrument that focuses its attention on the rights of victims and the obligations of States ${ }^{18}$.

In September 2011, the Human Rights Council appointed, through Resolution $18 / 7$, a Special Rapporteur on the promotion of truth, justice, reparation and guarantees of non-repetition in order to deal with transitional situations of an authoritarian regime or from a conflict where there have been serious human rights violations and flagrant violations of IHL. Today Fabian Salvioli is in charge.

\subsection{The Chicago Principles on Transitional Justice}

Taking into account what has happened in the world and the experiences of TJ, in 2007 the "Chicago Principles on Transitional Justice" were adopted"19 that today play an important role in the adoption of public policies by States to deal with serious crimes and have been used in various transition processes ${ }^{20}$. Although they are soft laws, they are important because they constitute parameters to be taken into account and a frame of reference regarding where to go.

\footnotetext{
15. Cfr. https://undocs.org/es/S/2004/616, p.1 (Accessed 17 March 2020)

16. https://undocs.org/es/S/PRST/2010/11, p. 2 (Accessed 19 March 2020)

17. https://undocs.org/es/A/RES/60/147, 21 March 2006.

18. See also: Report by Diane Orentlicher, independent expert charged with updating the set of principles for the fight against impunity - Updated set of principles for the protection and promotion of human rights through the fight against impunity,

file://C:/Users/fquispe/Downloads/E_CN.4_2004_88-ES.pdf, of February 27, 2004. https://undocs.org/ pdf?symbol=es/E/CN.4/2005/102, of February 18, 2005.

19. This is a joint project of the "International Human Rights Law Institute", "Chicago Council on Global Affairs", Istituto Superiore Internazionale di Scienze Criminali” andthe "Association Internationale de Droit Pénal”.

20. https://www.ictj.org/es/que-es-la-justicia-transicional. (last visit March 20, 2020)
} 
These principles are:

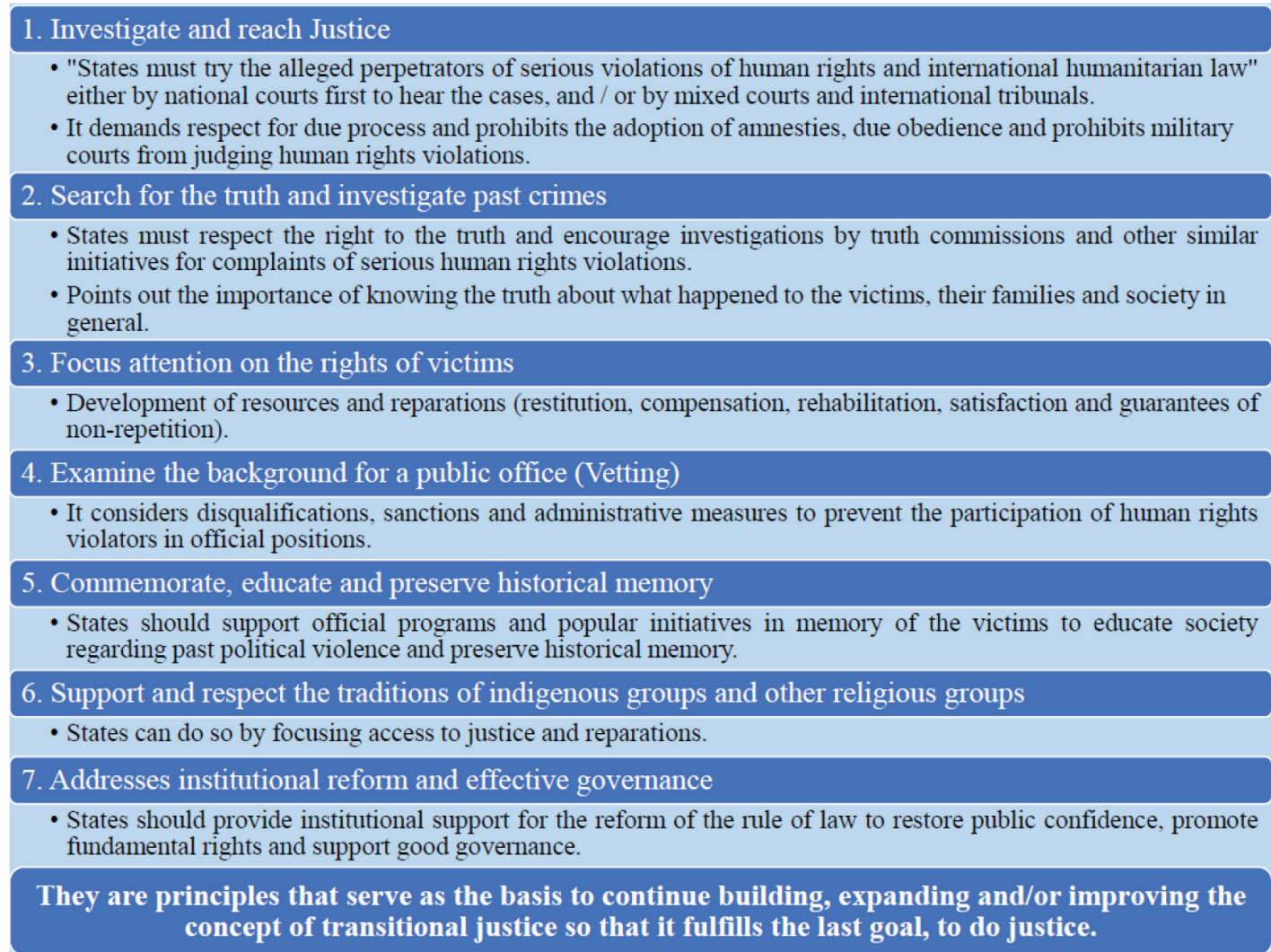

Source: own elaboration

\section{Transitional Justice in the Inter-American Human Rights System}

\subsection{Brief reference to the creation of transitional Justice in Latin America and the Inter-American human rights system}

As we have seen previously in the Latin American region, unfortunately as a consequence of the great and serious violations of human rights, it has played an important role in the origin and development of the concept of transitional justice.

Argentina under the government of Jorge Videla, from 1976 to 1981, lived through a dictatorship, where human rights were violated, although the reorganization process lasted until December 5, 1983 because there were still military boards that were definitively dissolved on December 5, 1983. On December 15, 1983, Argentina pioneered in the creation of the National Commission on the disappearance of persons, known today as truth commissions, a characteristic feature of transitional justice, whose impact has 
been long lasting at the global and regional level ${ }^{21}$. Many agree on the contribution of this country to the development of the JT because it was often the instigator of new specific mechanisms and not a mere recipient of justice (SIKKINK \& WALLING, 2006, p. 308).

Chile also learned about the consequences of the repression by Augusto Pinochet's military regime from September 1973 to March 1990. In April 1990, Chilean President Patricio Aylwin also formed a National Commission for Truth and Reconciliation (SMITH, 2009, p. 99) 22 .

On the other side of the world, in South Africa, after the serious consequences that the regime of racial segregation (apartheid) had for human beings, in 1995 the government of South Africa created the Truth and Reconciliation Commission. With this act, it publicly acknowledged past human rights violations for the first time ${ }^{23}$.

Given this background, later different types of commissions have been created more frequently. This is the case for El Salvador, Peru, Haiti, Guatemala, Morocco, Sierra Leone, among others (HAYNER, 2006, p. 18) ${ }^{24}$. In Latin America and in other parts of the world, truth commissions have revealed the atrocities of the predecessor regime. Today, these serious and great violations of human rights are not forgotten and the States face this problem, adopting political, economic and social measures aimed at the restoration of justice, reconciliation and the maintenance of peace. The truth commission emerged as an antidote to impunity and an analogue to amnesty. "Throughout the Americas -Argentina, Chile, El Salvador, Honduras, Haiti and Guatemala- wherever the violence was massive in relation to the population, mitigating the possibility of criminal reprisals, the truth commission became a central mechanism for the possibility of political transition" ${ }^{25}$. This does not mean in any case that these Commissions are perfect. HAYNER analyzes in detail more than twenty Truth Commissions created in different parts of the world, for which the great challenges and various problems that these commissions face are noted (HAYNER, 2008, p. 432).

Unfortunately, in many cases decades have elapsed for the State to accept the mistakes of the past and look to the future, recognizing rights. A large part of the violations of the

\footnotetext{
21. After the Argentine Truth Commission, four other Truth Commissions were established before the end of the decade. During the 1990s, thirteen new Truth Commissions were created and sixteen truth commissions were inaugurated between 2000 and mid-2004, including the first Truth Commission in the Middle East and North Africa region (Morocco 2004). Cfr. SIKKINK, Kathryn and WALLING Booth, Argentina's contributions to global trends in transitional justice, p.301-324, p.308 in Transitional Justice in the Twenty..., ob.cit. An extensive work on Truth Commissions can be seen at: KRITZ, Neil, Transitional Justice, Volume III, Laws, Ruling, and Reports, United State Institute of Peace Press, Washington, D.C. 1995. pp. 834.

22. However, their training was not intended to "gather ammunition for legal proceedings against army officers, but simply to document the truth and clear the air".

23. VENTURA, María, Reflections on the work of the South African Truth and Reconciliation Commission, Social Sciences Magazine, Nueva Época, No. 33, October 2012-March 2013, pp. 142-159; PICKER, Ruth, The sessions of the South African Truth and Reconciliation Commission perspectives from the victims, in Right to memory, GOMEZ ISA, Felipe (dir.), 2006, pp. 113-138.

24. See his work on Truth Commissions.

25. TEITEL, Ruti G., Transitional Justice, 2000, Oxford University Press, 2000, p. 79.
} 
seventies and eighties of the past century has been characterized by impunity and the neglect of the victims. Let us not forget that impunity is the breeding ground for all violations.

For many years and in different parts of the world it was affirmed from a pragmatist conception "that in transition situations it is necessary to accept large doses of impunity, to recognize the impossibility of prosecuting, judging and punishing the great perpetrators of human rights violations. and admit that the application of national or international justice is impossible", and this was done in post-Franco Spain, in Portugal, Brazil, the countries of the Southern Cone of Latin America, the Philippines, countries in Africa and the end of the civil wars in Central America. This was due to the active participation during the negotiations of the members of the previous regime in the definition of power relations (CORTÉS RODAS, 2007, p. 65).

Since the end of the 20th century, there has been an almost generalized commitment to the establishment of democratic societies where respect for human rights and recognition of the victims prevail. The intention has been to build democratic societies that respond to the needs of the victims. To this, it contributes to the development of human rights protection systems and the development of International Criminal Law. The vast majority of these systems have bodies, judicial or not, that are aware of human rights violations and over the years they have spoken out about these violations. Among them, there is what is known as the Inter-American Human Rights System.

The inter-American system is understood to be all the normative production on human rights that has been carried out by an initiative of the States within the framework of the Organization of American States (OAS) since 1948. Added to this is the production through resolutions and judgments of the organs of the Inter-American System for the protection of human rights, the Commission and the Inter-American Court, created in 1959 and 1969, respectively (QUISPE REMÓN, 2019, p. 34).

Many people who are under the jurisdiction of the States that are now part of the IAHRS have suffered serious violations (Chile, Argentina, Peru, Colombia, etc.). The SIDH was created with the adoption of the American Declaration of the Rights and Duties of Man in 1948 and is consolidated with the adoption of the American Convention on Human Rights in 1969 (ACHR), a binding instrument that creates the Commission and the Inter-American Court as organs of the System (QUISPE REMÓN, 2010, pp. 297343), (QUISPE REMÓN, 2019, pp. 34-73).

The Inter-American Court began its operation in 1978, almost in parallel with the great dictatorships in the Latin American region. This means that said body did not have the support of all the States in the region ${ }^{26}$. At the end of the period of the dictatorships,

\footnotetext{
26. For example. Argentina signed and ratified the American Convention on Human Rights in February 1984, while Chile signed the American Convention in 1969, but only ratified it in October 1990; Paraguay and Uruguay signed the Convention in 1969 but ratified it in August 1989 and March 1985, respectively; Brazil signed and ratified in 1992.
} 
the States have gradually joined the IHRS. Today we find many pronouncements of the Court on the violation of human rights that occurred in that period. Although it is true that International Law is not retroactive, the Court resorted to continuing crimes to learn about the events that occurred, even prior to their existence, and to condemn the States (I/A Court HR, 2006a) (I/A Court HR, 2006b) (I/A Court HR, 2011a).

The Court throughout its existence has always issued very progressive and pro homini judgments and advisory opinions. It is worth highlighting its resounding pronouncement, from the Barrios Altos case against Peru (2001), on the inadmissibility of the amnesties ${ }^{27}$ pardons, prescriptions or other exclusion of responsibility whose objective is to prevent the investigation and punishment of those responsible for serious human rights violations (QUISPE REMÓN, 2010, p. 359). However, in the Mozote v. E1 Salvador case (2012), it makes an exception, and performs an analysis of compatibility of the General Amnesty Law for the Consolidation of Peace with the international obligations of the ACHR in light of Additional Protocol II to the Geneva Conventions of 1949. It is taken into account that it is a general amnesty law that refers to acts committed in the context of an internal armed conflict, and indicates that according to International Humanitarian Law, the issuance of amnesty laws for the cessation of hostilities in non-international armed conflicts to enable a return to peace" (I/A Court HR, 2012a, 284-285 pars).

Since the Castillo Petruzzi v. Peru case (1999) it has also been arguing that the military courts are not competent to hear cases on human rights violations in any case (QUISPE REMÓN, 2010, pp. 379-386), inasmuch as, the Court says, they are incompatible with the American Convention.

\subsection{The Inter-American Court and its development of transitional justice elements}

The protection bodies of the IHRS, the Commission and the Inter-American Court have played and continue to play an important role in the development of the search for the truth and the recognition of the rights of the victims, essential elements of the TJ. However, this article only focuses its attention on the role of the judicial organ of the interAmerican system, the Inter-American Court ${ }^{28}$.

\footnotetext{
27. Although this firmness over time has been relativized, in the case of El Mozote.

28. The Inter-American Commission has repeatedly ruled on transitional justice. As an example, one of the latest actions can be cited. In 2019, it created the Rapporteur ship on Memory, Truth and Justice. In 2019, it adopted Resolution 3/2019 in which it recognizes the 16 "Principles on Public Policies on Memory in the Americas": Comprehensive approach to memory, participation of victims, involvement of civil society, suitability of persons in charge of memory policies, interdisciplinarity, intercultural approach and focus, regional integration, financing, design and implementation of memory initiatives, regulatory framework, identification and signaling, construction or recovery and preservation, sustainable management, creation or recovery, preservation and sustainable management, accessibility of state archives, restrictions on access to information in state archives.
} 
In jurisprudence, we will not find an explicit reference to the term transitional justice, but a broad development on the elements or characteristics of transitional justice described in the first part of the work.

The Court, whose purpose is not to condemn the State, nor to assume its obligations, but to protect the rights recognized in the ACHR for individuals and to rule on the matter and, where appropriate, determine whether or not the State was responsible for the violation of the ACHR, issued its first judgment in the Velásquez Rodríguez case (I/A Court HR, 1988) a decade after its operation. Despite being the first sentence, it is, for the purposes of the TJ, a valuable contribution because it establishes that all States parties have a legal duty to: Adopt the necessary measures to reasonably prevent human rights violations; Investigate in a responsible and serious manner with the means at its disposal the violations committed within the scope of its jurisdiction in order to identify those responsible; impose the pertinent sanctions on those responsible for the violations and guarantee adequate reparation for the victims (I/A Court HR, 1988, para. 174). Aspects that have been and are developed by States in transition stages.

For the Court, States have the obligation to respect the rights and freedoms recognized in the ACHR in such a way that any action or omission of any public authority that undermines human rights is attributable to the State (I/A Court HR, 1988, para. 164). This implies the organization of the entire state apparatus and all the structures, through which public power manifests itself, so that they are capable of legally ensuring the free and full exercise of human rights. "As a consequence of this obligation, the States must prevent, investigate and punish any violation of the rights recognized by the convention and also seek the reestablishment, if possible, of the violated right and, where appropriate, the reparation of the damage caused by the violation of human rights" (I/A Court HR, 1988, para. 164).

For the Court, it is a principle of international law that the State responds "for the acts of its agents carried out under their official status and for their omissions, even if they act outside the limits of their jurisdiction or in violation of domestic law". (I/A Court HR, 1988, para. 170). This principle is perfectly suited to the nature of the Convention, which is violated in all situations in which public power is used to harm human rights recognized in it. Otherwise, the protection system established in the Convention would become illusory (I/A Court HR, 1988, para. 171).

The Court says that the obligation to prevent, investigate and punish human rights violations does not end solely for actions of the public powers, but also for illegal acts that violate human rights that are not directly attributable to a State, "for example, because it was the work of an individual or because the perpetrator of the transgression was not identified, due to lack of due diligence to prevent the violation or treat it in accordance with the Convention "(I/A Court HR, 1988, para. 172).

Thus, the obligation to investigate and to prevent is an obligation of means or behavior that is not breached just because the investigation does not have positive results. The State must do so seriously and not as a mere formality, condemned in advance to be unsuccessful. It must assume it as its own legal duty and not as a simple management of 
private interests, "which depends on the procedural initiative of the victim or their next of kin or the private contribution of evidence, without the public authority actually searching for the truth". "This assessment is valid regardless of the agent to whom the violation may eventually be attributed, even individuals, because, if their facts are not seriously investigated, they would be, in a certain way, aided by the public power, which would compromise international responsibility of the State" (I/A Court HR, 1988, para. 177).

In Velásquez Rodriguez, the Court turns to the principle of International law of the identity or continuity of the State and affirms that the responsibility subsists regardless of changes of government over time and, specifically, between the moment in which the wrongful act is committed that generates responsibility and the one in which it is declared. This is valid, says the Court, also in the field of human rights, although from an ethical or political point of view, the attitude of the new government is much more respectful of these rights than that of the government at the time when the violations occurred" (I/A Court HR, 1988, para. 184).

Since then it has made reference to various concepts that today are developed as essential elements of TJ. This is the case of the right to the truth that the victims and the victims' next of kin must obtain ${ }^{29}$, as well as the concept of victim that goes beyond the person who has directly suffered the violation of their human rights and the responsibility that the State has in the prevention and protection of human rights of all those who are under its jurisdiction. It makes it clear that the States are those most responsible for protecting and guaranteeing the effective exercise of the rights recognized in the ACHR to all people, they are in charge of not leaving the violation of human rights unpunished. It is also true that the Court makes a broad interpretation of the ACHR, since from the literal text it is difficult to notice the developments that we find today in its decisions regarding elements of transitional justice such as the right to truth, reparations and its modalities or the extension and recognition of certain rights of the victims' next of kin, etc.

\subsubsection{The next of kin of victims and their consideration as victims by the Inter-American Court}

The actions of the TJ will always assume serious violations of human rights, which have left victims who have suffered "in their own flesh" the torture, disappearances, etc., (direct victims) and others who have suffered as a result of these violations, parents, children, etc. (indirect victims).

The ACHR warns that the human rights recognized in it are for any person whose rights have been violated, and that once domestic remedies have been exhausted, it can activate the competence of the protection bodies. The person or group of people

\footnotetext{
29. A concept that is difficult to define, which arose at the national, regional and international levels and refers to the obligation of the States with respect to the victims, their next of kin and society as a whole to provide information on the circumstances in which the violations of human rights were committed. (NAQVI, P., 2006)
} 
whose rights have been violated are called victims. The ACHR does not classify victims as direct and indirect, but it follows that the rights embodied in it are for people whose rights have been directly violated. There is no concept of victim. In this context, the Inter-American Court, taking into account the reality of the region and the great violations of human rights, makes a broad interpretation of the ACHR and extends various human rights to the families of the victims. In the Blake v. Guatemala case, for the first time, it extends Human Rights recognized in the ACHR to the victims' next of kin, pointing out that Article 8.1 of the ACHR, referring to judicial guarantees / due process, "must be interpreted in a broad manner so that said interpretation is based both on the literal text of that norm and on its spirit, and must be appreciated in accordance with Article 29, paragraph c) of the Convention, according to which no provision of the same can be interpreted with exclusion of the other rights and guarantees inherent to the human being or derived from the representative democratic form of government"(I/A Court HR, 1998, para. 96). It concludes that article 8.1 also includes the right of the victim's next of kin to judicial guarantees, since "any act of forced disappearance removes the victim from the protection of the law and causes him serious suffering, the same than his family". This right confers on Mr. Blake's next of kin the right to have his disappearance and death effectively investigated by the Guatemalan authorities; to follow a process against those responsible for these crimes; that the pertinent sanctions be imposed on them, and that the damages suffered by said next of kin be compensated" (I/A Court HR, 1998, para. 97) ${ }^{30}$.

A year earlier, in the Castillo Páez case against Peru, it had already been mentioned that it is the obligation of the State to investigate the facts, despite the internal order difficulties that may exist, until they are fully complied with, since "the right of the victim's next of kin subsists to know what their fate was and, where appropriate, where their remains are found"31. Added to this duty to investigate is that of preventing the possible commission of forced disappearances and punishing those responsible for them (I/A Court HR, 1997, para. 90). It condemned the Peruvian State for the violation of Article 5 of the ACHR, to the detriment of Mr. Castillo Páez and his next of kin, referring to the right to an effective recourse before the competent national judges or courts, the State having to make reparations for the consequences of the violations and compensate the victims' next of kin.

For the Court, the violation of the mental and moral integrity of the next of kin is a direct consequence of forced disappearance, since it generates suffering and anguish, as well as a feeling of insecurity, frustration and impotence in the face of the abstention of the public authorities from investigating facts. In addition, in the Blake case, it pointed out that the cremation of the mortal remains with the aim of destroying evidence that violated the cultural values inherited from generation to generation in Guatemala, intensified the pain of the relatives. Therefore, this suffering to the detriment of the mental and moral

\footnotetext{
30. This criterion has been reiterated in subsequent cases, among others, (I/A Court HR, 1999); (I/A Court HR, 2000a, para. 130); (I/A Court HR, 2011b, para.187); (I/A Court HR, 2005c, para. 63); (I/A Court HR, 2011a, para. 120); (I/A Court HR, 2012d, para. 199)

31. Criterion that is later repeated, among others, in (I/A Court HR, 2002, para. 114).
} 
integrity of the family members constitutes a violation by the Rule of law established in art. 5 of the ACHR (I/A Court HR, 1998, para. 114-115). ${ }^{32}$

In many cases, it has ruled on the violation of this article to the detriment of the victims' next of kin. In the Mapiripán Massacre case, it stated that the victim's relatives not only have had their physical and psychological integrity affected, but also their social and work relationships, and the dynamics of their families altered, and, in some cases, the life and personal integrity has been put at risk (I/A Court HR, 2005a, para 212). For the Court, the evidence in situations of serious violations is irrelevant, "no evidence is needed to demonstrate the serious effects on the mental and emotional integrity of the next of kin of the victims" (I/A Court HR, 2005a, para. 212). In addition, given the circumstances of the case in which it was not possible to have more information on other relatives of the victims, it was considered reasonable "to presume that all of them, identified and unidentified, suffered the extreme circumstances of the massacre or its consequences" (I/A Court HR, 2005a, para. 212). It declared all the next of kin (individualized or not) victims of the violation of the right to personal integrity.

In the Myrna Mack Chang case, it also considered the immediate family members victims of violation of personal, mental and moral integrity, due to the threats and harassment suffered since the beginning of the investigation of the extrajudicial execution, and the pattern of obstructions of the investigations through mechanisms that even affected justice operators (I/A Court HR, 2003a, para. 232).

In Villagrán Morales, it once again points out that victims of human rights violations or their family members must have "ample opportunities to be heard and act in the process projects, both in seeking to clarify the facts and punish the responsible parties, as well as seeking due reparation" (I/A Court HR, 1999). It affects the suffering of mothers as a result of the negligence of the authorities who did not make adequate efforts to locate the families of the victims and notify them of the deaths in order to bury them $^{33}$. The treatment given to the bodies of the victims (abandonment in an uninhabited area and exposure to inclement weather and the action of animals), which were sacred to their relatives, especially their mothers, was cruel and inhumane treatment. It links the continuous deprivation of the truth about the disappearance of the detainee with cruel, inhumane and degrading treatment for close relatives (I/A Court HR, 2002, para. 114).

Although the Court has mentioned family members in general, throughout its jurisprudence it has perfected and outlined this concept, incorporating guidelines from the jurisprudence of the European Court of Human Rights (ECHR), which also considers family members as victims of human rights violations. In the Bámaca Velásquez case, it includes the elements that the ECHR establishes in the case of Kurt v. Turkey, of May 25, 1998. The ECHR ruled on the condition of victim of cruel, inhuman and degrading treatment of a mother

\footnotetext{
32. Criterion reiterated in (I/A Court HR, 2004a, 210-211 par.) In this case, the Court also pronounces on the pain and uncertainty of the next of kin by not knowing the whereabouts and by not being able to honor their remains in accordance with their beliefs and customs (para. 212).

33. Criterion that is reiterated in (I/A Court HR, 2003c, para. 102)
} 
whose son had been detained and disappeared, assessing the circumstances of the case, the seriousness of the mistreatment and the fact that she did not have official information to clarify the facts. It concluded by considering the mother as the victim and attributed to the State the violation of 3 of the European Convention on Human Rights (ECHR) (I/A Court HR, 2000b, para. 162). Subsequently, the Inter-American Court refers to the Cakici and Timurtas cases, both against Turkey, of 1999 and 2000, respectively, in which the ECHR mentions other elements, to be taken into account for the classification of victim, such as "the proximity of the family bond, the particular circumstances of the relationship with the victim, the degree to which the relative witnessed the events related to the disappearance, the way in which the relative became involved regarding attempts to obtain information about the disappearance of the victim and the response offered by the State to the proceedings initiated" (I/A Court HR, 2000b, para. 163). Thus, the Court, assessing the circumstances of the case and taking into account the continuous obstruction of the family member's efforts to learn the truth of the facts, especially about the concealment of the body of Bámaca Velásquez, as well as the obstacles by the authorities to the exhumation attempts and the official refusal to provide the corresponding information, considered that the sufferings the family member was subjected to constituted cruel, inhuman and degrading treatment (articles 5.1 and 5.2 of the ACHR). Added to this is the deep anguish of their next of kin for not knowing their whereabouts, which is why they are considered victims of the violation of Article 5.1 and 5.2 of the ACHR (I/A Court HR, 2000b, para. 165).

In 2006, in the Heliodo Portugal case, it stated six criteria to determine the condition of victims of the violation of the right to mental and moral integrity due to the suffering they have suffered and due to the subsequent actions or omissions of the authorities in the face of the facts. These are:

“1) existence of a close family bond;

2) the particular circumstances of the relationship with the victim;

3) the way in which the family member became involved in the search for justice;

4) the response offered by the State to the steps taken;

5) the context of a "regime that prevented free access to justice", and

6) the permanent uncertainty in which the victim's next of kin were involved as a consequence of the ignorance of his whereabouts" (I/A Court HR, 2008b, para. 163).

Knowing what happened to the disappeared person, the facts, the whereabouts of his mortal remains constitutes for the next of kin a measure of reparation, "and therefore an expectation that the State must satisfy the next of kin of the victim and society as a whole" (I/A Court HR, 2002, para. 114) ${ }^{34}$. It is an act of justice and reparation in itself, to

34. Along the same lines in (I/A Court HR, 2014, para. 481) 
deliver the mortal remains in the case of disappeared detainees. "It is an act of justice to know the whereabouts of the disappeared, and it is a form of reparation because it allows dignifying the victims, since the mortal remains of a person deserve to be treated with respect towards their relatives and in order that they can give him an adequate burial" (I/A Court HR, 2002, para. 115). Thus, it recognizes certain human rights to the families of the victims, such as the right to the truth.

\subsubsection{The right of victims to the right to the truth according to the Inter-American Court}

The ACHR does not recognize the right to the truth as a human right, but given the context of the region, the Court has been introducing this concept, especially in crimes related to forced disappearance, even pointing out that it is a right of the victims and their families ${ }^{35}$. Already in its first sentence it refers to the obligation of the public authority to effectively seek the truth about the events that occurred (I/A Court HR, 1988, para. 177). The State must satisfy the right of the victim's next of kin to know where he is and, if necessary, indicate the place of his remains (I/A Court HR, 1988, para. 181).

The Court, taking into account the decisions of the Human Rights Committee and the UN Human Rights Commission, in the Bámaca Velásquez case, recognizes that the right that everyone has to the truth has been developed by international human rights law (I/A Court HR, 2000b, para. 76), and in the case of Myrna Mack Chang, it held that "everyone, including the next of kin of victims of serious human rights violations, has the right to the truth (I/A Court HR, 2003a, para. 274) ${ }^{36}$. The Court does not consider that this right is an autonomous right set forth in Articles 8, 13, 25 and 1.1 of the ACHR, but rather that it is a right "subsumed in the right of the victim or their next of kin to obtain from the competent organs of the State the clarification of the violating facts and the corresponding responsibilities, through the investigation and prosecution" (I/A Court HR, 2005b, para. 62). It reiterates in its sentences the importance of knowing the truth about what happened on the part of the victim of serious human rights violations and their next of kin, to know the whereabouts of their remains and their recognition, since they can constitute an important means of reparation.

For the Court, the right to the truth is part of the right of access to justice, that is, it is framed within this right "as an expectation that the State must satisfy the victims of human rights violations and their next of kin and as a form of reparation (I/A Court HR, 2006c, para. 219) ${ }^{37}$. Therefore, in its jurisprudence it has analyzed the right to the truth within Articles 8 and 25 of the Convention, as well as in the chapter on other forms of

\footnotetext{
35. In the universal sphere, we find the antecedent to this right in Resolution 9/11 of September 24, 2008. Human Rights Council. The right to the truth, A / HRC / RES / 9/11.

36. Along the same lines, among others, in (I/A Court HR, 2002, para. 114); (I/A Court HR, 2004b, para. 81); (I/A Court HR, 2004a, para. 26); (I/A Court HR, 2004c, para. 230); (I/A Court HR, 2004d, para. 257); (I/A Court HR, 2004e, para. 97); (I/A Court HR, 2004f, para. 128); (I/A Court HR, 2005c, para. 62).

37. Along the same lines in (I/A Court HR, 2009, para. 118); (I/A Court HR, 2010, para. 201)
} 
reparation" (I/A Court HR, 2006c, para. 219). The truth is subsumed in the right of the victim or his next of kin to obtain from the competent organs of the State the clarification of the violating facts and the corresponding responsibilities, through the investigation and prosecution that articles 8 and 25 of the ACHR provide (I/A Court HR, 2007, para. 147). The power to access justice must ensure in a reasonable time that the victims and their next of kin know the truth of what happened, ensure an investigation, prosecution, and, where appropriate, the punishment of those responsible (I/A Court HR, 2003b, para. 114) (I/A Court HR, 2006d, para. 382) ${ }^{38}$. It has linked the right to know the truth "with the Ordinary Action filed by the next of kin, which is linked to access to justice and the right to seek and receive information enshrined in Article 13 of the American Convention" (I/A Court HR, 2010, para. 201). For the Court, the right to the truth is part of access to justice and is broad in nature, the violation of which may affect various rights recognized in the ACHR depending on the context and circumstances of the case (I/A Court HR, 2015, para. 265).

The Court has adopted decisions on the basis of noting the existence of rights such as the right to truth or the right to water based on the content of others that arise from applicable conventional texts (I/A Court HR, 2020b, para. 211).

In the Gudiel Álvarez case, the Court relies on the opinion of the United Nations regarding the importance of determining the truth regarding human rights violations for the consolidation of peace and reconciliation, an argument that finds support in IHL that recognizes that the next of kin have the right to know the truth about the fate of the disappeared victims, including victims of forced disappearances, both in international and non-international armed conflicts (I/A Court HR, 2012b, para. 299) ${ }^{39}$.

For the Court, not knowing the truth about the fate of a disappeared person constitutes a form of cruel and inhumane treatment for close relatives (I/A Court HR, 2011b, para. 133). In a democratic society, the truth about the serious human rights violations that occurred must be made known, since this constitutes a just expectation that the State must satisfy (I/A Court HR, 2012c, para. 194).

The inherent obligations of the right to the truth in cases of serious human rights violations require the adoption of institutional designs that allow this right to be carried out in the most suitable, participatory and complete way possible and not face legal or practical obstacles that make it illusory. The Court emphasizes that the satisfaction of the collective dimension of the right to the truth requires the determination of the most complete possible historical truth, which includes the judicial determination of the patterns of joint action and all the persons who in various ways participated in violations and their responsibilities (I/A Court HR, 2007, para. 195) ${ }^{40}$.

\footnotetext{
38. Along the same lines in the case (I/A Court HR, 2012c, para. 191); and recently in (I/A Court HR, 2020a, para. 173)

39. Along the same lines in (I/A Court HR, 2015, para. 262). The recognition within the UN, through its various human rights protection bodies, of the victims' right to the truth is highlighted. An imprescriptible truth.

40. Along the same lines in (I/A Court HR, 2008c, para. 102) and in (I/A Court HR, 2008a, para. 454)
} 


\section{Final Reflections}

Unfortunately, the world has experienced innumerable and grave human rights violations over the past centuries. Many of these events have gone unnoticed by the governments that came after violations by the previous regime, despite their gravity . In many cases, precisely in order not to activate or carry out investigations in the future and to leave violations unpunished, amnesty laws have been adopted, avoiding giving answers about the facts and events to the direct and indirect victims, who probably still suffer from the absence or the disappearance of their loved ones for which there was no action by the State.

In this context, the concept of transitional justice arises in order to avoid impunity, recognize the dignity of the victims, the right to know, to know the truth about what happened and that someone in the name of the State assumes that responsibility and makes reparation for the damages. After all, representing a state implies assuming the good and the bad. It is a step aimed at healing wounds where the State plays the leading role, paving the way, adopting the necessary mechanisms to avoid forgetting the great and serious violations of human rights. This involves the adoption of judicial mechanisms that facilitate access to justice for vulnerable groups, taking into account, if applicable, their needs; that they are in charge of investigating, punishing and condemning those responsible for human rights violations, or non-judicial ones, such as the establishment of suitable bodies, in charge of gathering information about the victims and the facts, leaving a record of what happened, always knowing the reality of the victims and empathizing with them; as well as the appointment of Truth Commissions, whose members must be suitably equipped to carry out said work, and their composition must take into account the knowledge of the reality of the victims and their needs and their idiosyncrasies. The ultimate goal of TJ is to obtain justice, understood as giving everyone what is their due. It is the obligation of the State at this stage to regain the trust of the population through proven institutions.

The development of international human rights law through international systems for the protection of human rights, whether at the universal or regional level, constitutes a retaining wall against impunity and represents a space of hope for the victims. Human rights constitute a limit to the absolute will of the States in the past and an obligation to guarantee and protect the rights of all persons under their jurisdiction. In this context, the bodies for the protection of human rights play an important role, especially the InterAmerican Court, which has been developing a broad interpretation of the American Convention to protect the victims and recognize certain human rights, such as the right to the truth and to the right to reparation, among others, linked to other rights, although their pronouncements have not been framed in transition processes. This allows victims to activate the jurisdiction of international bodies on the one hand and, specifically of the inter-American system, on the other, the obligation of the State to comply with the decisions emanating from the Inter-American Court, applying the conventionality control that the Court requires of the States that have assumed its contentious jurisdiction.

Undoubtedly, thanks to the application of transitional justice and according to the realities, we will be able to speak of a reconciled society, where respect for the human 
rights of the victims is a priority, on the one hand, and on the other, the fight against timpunity that has caused so much harm to thousands of people in the world, creating deep-rooted resentment and preventing peaceful coexistence.

\section{BibLIOGRAPHY}

CORTÉS RODAS, F., 2007. Los derechos de las víctimas de la violencia política a la verdad, la reparación y la justicia. Reflexiones sobre cuatro casos en América latina. Estudios Políticos, Issue 31.

DE GRIEFF, P., 2011. Algunas reflexiones acerca del desarrollo de la Justicia Transicional. Anuarios de Derechos Hmanos de la Universidad de Chile, Issue 7, pp. 17-39. HYPERLINK "https://doi.org/10.5354/0718-2058.2011.16994" \t "_blank" https://doi.org/10.5354/0718-2058.2011.16994

DE GRIEFF, P., 2012. Theorizing Transitional Justice. In: M. Williams, R. Nagy \& J. Elster, eds. Transitional Justice. New York: New York University Press, pp. 3177. HYPERLINK "https://doi.org/10.18574/nyu/9780814794661.003.0002" It " blank" https://doi.org/10.18574/nyu/9780814794661.003.0002

DORADO, J., 2015. Justicia transcional. Eunomía Revista en Cultura de la Legalidad, Issue 8.

GUEMBE, M. J. \& OLEA, H., 2006. No justice, no peace: Discussion of a legal framework regarding the demobilization of non-state armed groups in Colombia. In: N. RohtArriaza \& J. Mariezcurrena, eds. Transitional Justice in the Twenty-First Century. Beyond Truth versus Justice. Cambridge: Cambridge University Press, pp. 120142. HYPERLINK "https://doi.org/10.1017/CBO9780511617911.007" \t"_blank" https://doi.org/10.1017/CBO9780511617911.007

HAYNER, P., 2006. Comisiones de la Verdad: resumen esquemático. International Review of the Cross Red, Issue 862, pp. 1-18.

HAYNER, P., 2008. Verdades innombrables: El reto de las Comisiones de la Verdad. Ciudad de México: Fondo de Cultura Económica.

HUNTINGTON, S., 1994. La tercera ola, la democratización a finales del siglo XX. Barcelona: Paidós.

I/A Court HR, 1988. Caso Velásquez Rodríguez vs. Honduras, San José de Costa Rica: I/A Court HR.

I/A Court HR, 1997. Caso Castillo Páez vs. Perú, San José de Costa Rica: I/A Court HR.

I/A Court HR, 1998. Caso Blake vs. Guatemala, San José de Costa Rica: I/A Court HR.

I/A Court HR, 1999. Caso "Niños de la calle" (Villagrán Morale y otros) vs. Guatemala, San José de Costa Rica: I/A Court HR.

I/A Court HR, 2000a. Caso Durand y Ugarte vs. Perú, San José de Costa Rica: I/A Court HR. 
I/A Court HR, 2000b. Caso Bámaca Velásquez vs. Guatemala, San José de Costa Rica: I/A Court HR.

I/A Court HR, 2002. Caso Trujillo Oroza vs. Bolivia, San José de Costa Rica: I/A Court HR.

I/A Court HR, 2003a. Caso Myrna Mack Chang vs. Guatemala, San José de Costa Rica: I/A Court HR.

I/A Court HR, 2003b. Caso Bulacio vs. Argentina, San José de Costa Rica: I/A Court HR.

I/A Court HR, 2003c. Caso Juan Humberto Sánchez vs. Honduras, San José de Costa Rica: I/A Court HR.

I/A Court HR, 2004a. Caso 19 Comerciantes vs. Colombia, San José de Costa Rica: I/A Court HR.

I/A Court HR, 2004b. Casso Molina Theissen vs. Guatemala, San José de Costa Rica: I/A Court HR.

I/A Court HR, 2004c. Caso Hermanos Gómez Paquiyauri vs. Perú, San José de Costa Rica: I/A Court HR.

I/A Court HR, 2004d. Caso Tibi vs. Ecuador, San José de Costa Rica: I/A Court HR.

I/A Court HR, 2004e. Caso Masacre Plan de Sánchez vs. Guatemala, San José de Costa Rica: I/A Court HR.

I/A Court HR, 2004f. Caso Carpio Nicolle vs. Guatemala, San José de Costa Rica: I/A Court HR.

I/A Court HR, 2005a. Caso Masacre de Mapiripán vs. Colombia, San José de Costa Rica: I/A Court HR.

I/A Court HR, 2005b. Caso Blanco Romero y otros vs. Venezuela, San José de Costa Rica: I/A Court HR.

I/A Court HR, 2005c. Caso Hermanas Serrano Cruz vs. El Salvador, San José de Costa Rica: I/A Court HR.

I/A Court HR, 2006a. Caso Almonacid Arellano vs. Chile, San José de Costa Rica: I/A Court HR.

I/A Court HR, 2006b. Caso Goiburú vs. Paraguay, San José de Costa Rica: I/A Court HR.

I/A Court HR, 2006c. Caso Masacre de Pueblo Bello vs. Colombia, San José de Costa Rica: I/A Court HR.

I/A Court HR, 2006d. Caso Penal Castro Castro vs. Perú, San José de Costa Rica: I/A Court HR.

I/A Court HR, 2007. Caso Masacre de la Rochela vs. Colombia, San José de Costa Rica: I/A Court HR.

I/A Court HR, 2008a. Caso Gonzáles y Otras vs. Colombia, San José de Costa Rica: I/A Court HR. 
I/A Court HR, 2008b. Caso Heliodoro Portugal vs. Panamá, San José de Costa Rica: I/A Court HR.

I/A Court HR, 2008c. Caso Valle Jaramillo y Otros vs. Colombia, San José de Costa Rica: I/A Court HR.

I/A Court HR, 2009. Caso Anzualdo Castro vs. Perú, San José de Costa Rica: I/A Court HR.

I/A Court HR, 2010. Caso Gomes Lund y otros ("Guerrilha do Araguaja) vs. Brasil, San José de Costa Rica: I/A Court HR.

I/A Court HR, 2011a. Caso Barbini Duarte y otros vs. Uruguay, San José de Costa Rica: I/A Court HR.

I/A Court HR, 2011b. Caso Gelman vs. Uruguay, San José de Costa Rica: I/A Court HR.

I/A Court HR, 2012a. Caso Masacre de El Mozote y lugares aledaños vs. El Salvador, San José de Costa Rica: I/A Court HR.

I/A Court HR, 2012b. Caso Gudiel Álvarez y otros ("Diario Militar”) vs. Guatemala, San José de Costa Rica: I/A Court HR.

I/A Court HR, 2012c. Caso Masacre de Río Negro vs. Guatemala, San José de Costa Rica: I/A Court HR.

I/A Court HR, 2012d. Caso Nadage Dorzema y otros vs. República Dominicana, San José de Costa Rica: I/A Court HR.

I/A Court HR, 2014. Caso Rodríguez Vera y otros (Desaparecidos del Palacio de Justicia) vs. Colombia, San José de Costa Rica: I/A Court HR.

I/A Court HR, 2015. Caso Comunidad Campesina de Santa Bárbara vs. Perú, San José de Costa Rica: I/A Court HR.

I/A Court HR, 2020a. Caso Azul Rojas Marín y Otra vs. Perú, San José de Costa Rica: I/A Court HR.

I/A Court HR, 2020b. Caso Comunidades indígenas miembros de la Asociación Lhaka Honhat (Nuestra Tierra) vs. Argentina, San José de Costa Rica: I/A Court HR.

KASAPAS, G., 2008. An introduccion to the concept of transitional justice: Wester Balcans and UE conditional. UNISION Disscusion Papers, Issue 18, pp. 59-76.

MÉNDEZ, J., 1997. Accountability for Past Abuses. Human Rights Quarterly, 19(2), pp. 255-282. HYPERLINK "https://doi.org/10.1353/hrq.1997.0018" \t "_blank" https://doi.org/10.1353/hrq.1997.0018

NAQVI, P., 2006. El derecho a la verdad en el derecho internacional: ¿ficción o realidad?. International Review of the Red Cross, Issue 862.

O'DONNELLL, G. \& SCHEMITTER, P., 2003 Spring. Transitions from authoritarian rule: tentative cinclusions about uncertain democracies IN Transitional Justice Geneology. Harvard Human Rights Journal, Volume 16, p. 69. 
PAIGE, A., 2009. How "Transitions" Reshaped Human Rights: A conceptual history of Transitionl Justice. Human Rights Quaterly, 31(2), pp. 321-376. HYPERLINK "https://doi.org/10.1353/hrq.0.0069" \t "_blank" https://doi.org/10.1353/ hrq.0.0069

PION-BERLIN, D., 1995. To prosecute or to pardon? Humans Right Decision in the Latin Amercican Souther Cone. In: N. Kritz, ed. Transitional Justice. Volumen I General consideration. Washington DC: United States Institute of Peace Press, pp. 82-103.

QUISPE REMÓN, F., 2010. El debido proceso en el derecho internacional y en el sitema interamericano. Valencia: Tirant lo Blanch.

QUISPE REMÓN, F., 2019. Los derecho humanos en el sistema interamericano. Valencia: Tirant lo Blanch.

ROHT-ARRIAZA, N., 2006. The new landscape of transitional justice. In: N. RohtArriaza \& J. Mariezcurrena, eds. Transitional Justice in the Twenty-First Century. Beyond Truth versus Justice. Cambridge: Cambridge University Press, pp. 1-16. HYPERLINK "https://doi.org/10.1017/CBO9780511617911.001" It "_blank" https://doi.org/10.1017/CBO9780511617911.001

SCHABAS, W., 2006. The Sierra Leona Truth and Reconcilation Commission. In: N. Roht-Arriaza \& J. Mariezcurrena, eds. Transitional Justice in the Twenty-First Century. Beyond Truth versus Justice. Cambridge: Cambridge University Press, pp. 21-42. HYPERLINK "https://doi.org/10.1017/CBO9780511617911.003" \t "_blank" https://doi.org/10.1017/CBO9780511617911.003

SERSALE DI CERISANO, F., 2013. Justicia transicional en las Américas. El impacto del Sitema Interamericano. Revista IIDH, Issue 57, pp. 115-136.

SIKKINK, K. \& WALLING, B., 2006. Argentina's contribution to global trends in transitional justice. In: N. Roht-Arriaza \& J. Mariezcurrena, eds. Transitional Justice in the Twenty-First Century. Beyond Truth versus Justice. Cambridge: Cambridge University Press, pp. 301-324. HYPERLINK "https://doi. org/10.1017/CBO9780511617911.015" It "_blank" https://doi.org/10.1017/ CBO9780511617911.015

SMITH, P., 2009. La democratización em América Latina (traducción de Carmen Martínrz Gimeno). Madrid: Marcial Pons. HYPERLINK "https://doi.org/10.2307/j. ctv10rrb5z" \t "_blank" https://doi.org/10.2307/j.ctv10rrb5z

TEITEL, R., 2000. Transitional Justice. Oxford: Oxford University Press.

TEITEL, R., 2003. Transitional Justice Geneology. Harvard Human Rights Journal, Volume 16, pp. 69-94.

UN, General Secretariat, 2004. Informe del Secretario General al Consejo de Seguridad, S/2004/616, Nueva York: s.n.

UN, Human Right Committe, 1992. Observacion General No 20, 44 período de sesiones, Ginebra: s.n. 
WEBER, J., 2012. Forms of Transitional Justice. In: Transitional Justice. New York: New York University Press.

WILLIAMS, M., NAGY, R. \& ELSTER, J., 2012. Transitional Justice. New York: New York University Press.

ZALAQUETT, P., 1995. Confronting human rights violations commited by former goverments: principles and political constraints. In: N. Kritz, ed. Transitional Justice. Volumen I General Considerations. Washington DC: United States Institute of Peace Press, pp. 3-31.

Received: June $22^{\text {nd }} 2021$

Accepted: October $19^{\text {th }} 2021$

(c) (i) (ㅇ) $\ominus$ 